\section{Is harmonic scalpel good for radial artery harvesting?}

To the Editor,

We read the original investigation "Comparison of ultrasonically activated scalpel and traditional technique in radial artery harvesting; an electron microscopic evaluation" by Dumantepe et al. (1) with interest published in May issue The Anatolian Journal of Cardiology 2011; 11: 250-6. In the research 40 patients undergoing coronary bypass with radial artery harvesting were divided into two groups based on the use of the ultrasonic cautery (UC) and the electrocautery (EC). The patients were divided into subgroups of two different storage, either at room temperature or normothermic organ bath.

For radial artery harvesting, some research have proved shorter harvesting time, less spasm and less hemostatic clip usage with harmonic scalpel compared to electrocautery (2-4). Çıkırıkçıoğlu et al. (3) had summarized the mechanism of preventing vasospasm by endothelium dependent release of nitric oxyde and prostacyclin by ultrasonic stimulation, and by endothelium independent vasodilatation for direct effect of ultrasonic energy on the smooth muscle contractile protein complexes. However Dumantepe found ultrasonic cautery took longer time for the graft harvesting and had no advantages in flow rates.

In electron microscopic findings of the results, Dumantepe et al. (1) stated that degree of tissue edema was increased in UC group (EC vs. UC; $1.7 \pm 0.2,2.1 \pm 0.3, p<0.0001$, respectively). This result is also displayed in the which highlighted the disadvantage of ultrasonic cautery in causing tissue edema. But the latter explanation "A lesser degree of edema was observed in endothelium and tunica media in-group UC, but less significant when it was compared in-group EC" is confusing and seems contradictory to the result of "degree of tissue edema was increased in UC group" with a significant difference ("EC vs. UC; $1.7 \pm 0.2,2.1 \pm 0.3, p<0.0001$ ").

Dumantepe's research (1) showed ultrasonic cautery took longer time for the graft harvesting and had no advantages in flow rates. They also found ultrasonic cautery caused significant graft edema with electron microscopic evidence. Therefore the previously established common view of advantages in using ultrasonic cautery for arterial graft harvesting should be debated again. More randomized controlled trials or meta-analysis about harmonic scalpel application in radial artery harvesting is needed.

By the way, in the abstract Dumantepe et al. (1) mentioned "Harvesting time, use of hemostatic clips, frequency of spasm, in situ free flow, temperature and endothelial damage were compared between the two groups". But we did not find the data of hemostatic clips or frequency of spasm in the result section. We are now conducting a meta-analysis which needs clips number and spasm rate in patients whose radial arteries are harvested. Could we have these data from Dr. Mert Dumantepe later?

\section{Ganglan Fu, Meng Wang}

Department of Cardiac Surgery, Sun Yat-sen Memorial Hospital, Sun Yat-sen University; Guangzhou-China

\section{References}

1. Dumantepe $M$, Kehlibar T, Güllü AU, Arslan Y, Yılmaz M, Berköz K, et al. Comparison of ultrasonically activated scalpel and traditional technique in radial artery harvesting; an electron microscopic evaluation. Anadolu Kardiyol Derg 2011; 11: 250-6.

2. Georghiou GP, Stamler A, Berman M, Sharoni E, Vidne BA, Sahar G. Advantages of the ultrasonic harmonic scalpel for radial artery harvesting. Asian Cardiovasc Thorac Ann 2005; 13: 58-60. [CrossRef]
3. Çıkırıkcıoğlu M, Posacıoğlu H. Harmonic scalpel has acute beneficial effects during radial artery harvesting. Asian Cardiovasc Thorac Ann 2006; 14: 89-90. [CrossRef]

4. Fawzy HF. Harvesting of the radial artery for coronary artery bypass grafting: comparison of ultrasonic harmonic scalpel dissector with the conventional technique. J Card Surg 2009; 24: 285-9. [CrossRef]

Address for Correspondence: Dr. Meng Wang,

N0.107, Yanjiangxi Road

Department of Cardiac Surgery, Sun Yat-sen Memorial Hospital, Sun Yat-sen University, Guangzhou-China

Phone: +86-02081332253

E-mail: surgeonwm@outlook.com

Available Online Date: 22.08.2014

(C) Copyright 2014 by Turkish Society of Cardiology - Available online at www.anakarder.com DOl:10.5152/akd.2014.5480

\section{Author`s Reply}

To the Editor,

Although we have reviewed our records with my co-authors following our receipt of this letter to the editor, unfortunately, we could not find the "clip number" data which was not included in the results section of our study as it did not reflect the main purpose of the study.

\section{Mert Dumantepe \\ Department of Cardiovascular Surgery, Dr. Siyami Ersek Thoracic and Cardiovascular Surgery Research and Training Hospital; İstanbul-Turkey}

Address for Correspondence: Dr. Mert Dumantepe, Siyami Ersek Göğüs ve Kalp Damar Eğitim ve Araştırma Hastanesi, Kalp Damar Cerrahisi Bölümü, İstanbul-Turkey

Phone: +902165452858

Fax: +9021657066 11

E-mail: mdumantepe@gmail.com

Available Online Date: 22.08.2014

\section{Aortic stiffness evaluation in patients with metabolic syndrome; antihypertensive drugs and statins should be considered}

To the Editor,

I read the article "Impaired coronary flow reserve evaluated by echocardiography is associated with increased aortic stiffness (AS) in patients with metabolic syndrome: an observational study" by Tok et al. (1) with great interest published in May issue The Anatolian Journal of Cardiology 2013; 13: 227-34. They evaluated whether there is an independent association of impaired coronary flow and aortic elasticity in patients with metabolic syndrome. In the metabolic syndrome group, aortic dispensability was decreased and AS was significantly increased. In multivariate linear regression analysis, AS, systolic blood pressure and waist circumference had an independent relationship with impaired coronary flow reserve. I congratulate the authors for this well designed 